\title{
Experimental investigation on mechanical and tribological behaviour of surfactant coated multi-walled carbon nano tubes reinforced aluminium 6065-silicon metal matrix composite
}

\author{
J.P. Savina ${ }^{\dagger, 1}$, B. V. Raghavendra ${ }^{1}$, D. Rangappa ${ }^{2}$ \\ †mailtosavin@gmail.com

\begin{abstract}
${ }^{1}$ Department of Mechanical Engineering, JSS Academy of Technical Education, Bangalore, 560060, India ${ }^{2}$ Department of Nanotechnology, PG Center, Visvesvaraya Institute of Advanced Technology, Visvesvaraya Technological University, Muddenahalli, Chikkaballapur, 56210, India
\end{abstract}

\begin{abstract}
Metal matrix composites are widely preferred in engineering applications because of its enhanced properties as compared to base materials. Carbon nanotubes have evolved to be an excellent reinforced material to aluminium alloy metal matrix composites (MMCs). However, CNTs tend to agglomerate which further affect the properties of the composite materials. Obtaining agglomeration free composites is a challenging task and needs to be studied in the present scenario. Surface modification of the nanoparticles is one of the methods which would reduce the agglomeration problem. Hence, emphasis in this work is made on a coating of CNTs using sodium dedosile sulphate (SDS). In the present appraisal, SDS coated CNTs reinforced Al6065-Si base metal was fabricated by stir casting process. The weight percentage of the CNT is varied from 0.5 to $4 \mathrm{wt}$ \% for preparation of test specimens. This paper focuses on experimental study of mechanical and tribological behavior of composites such as compressive strength, hardness, tensile strength and abrasive strength for different wt.\% of CNTs. Microstructure of the composites is studied using FESEM apparatus. The experimental result shows good dispersion stability with increase in hardness, tensile strength and reduced wear loss of the CNTs reinforced Al-6065-Si.
\end{abstract}

Keywords: MWCNT (multi-walled carbon nanotube), CNTs (carbon nanotubes), mechanical properties, SDS (sodium dedosile sulphate).

УДК: 539.4

\section{Экспериментальное исследование механических}

и трибологических свойств армированных многослойными углеродными нанотрубками с поверхностно-активным

\section{покрытием металломатричного композита \\ алюминий 6065-кремний}

\author{
Савина Дж. П. ${ }^{\dagger, 1}$, Рагхавендра Б. В. ${ }^{1}$, Рангаппа Д. ${ }^{2}$ \\ ${ }^{1}$ Кафедра машиностроения, Академия технического образования JSS, Бангалор, 560060, Индия \\ ${ }^{2}$ Кафедра нанотехнологий, Центр PG, Институт перспективных технологий Висвесварая, Технологический \\ университет Висвесварая, Мудденахалли, Чиккабаллапур, 56210, Индия
}

Композиты с металлической матрицей широко используются в машиностроении из-за их улучшенных свойств по сравнению с основными материалами. Углеродные нанотрубки (УНТ) представляют собой отличный армирующий материал для композитов с металлической матрицей из алюминиевого сплава. Однако УНТ имеет тенденцию к агломерации, что дополнительно влияет на свойства композитных материалов. Получение композита, не содержащего агломерации, является сложной задачей и требует изучения. Модификация поверхности наночастиц является одним из методов, который может уменьшить проблему агломерации. Поэтому в данной работе особое внимание уделяется покрытию УНТ с использованием дедосилсульфата натрия. В настоящем исследовании композиты Al6065-Si, армированные УНТ с покрытием из дедосилсульфата натрия, изготовлены методом литья с перемешиванием. Массовая доля УНТ варьируется от 0.5 до 4 мас.\% при подготовке образцов для испытаний. Эта статья посвящена экспериментальному исследованию механических и трибологических свойств композитов, таких как прочность на сжатие, твердость, прочность на разрыв и абразивная прочность для различных масс.\% 
УНТ. Микроструктура композитов исследована на аппарате FESEM. Экспериментальный результат показывает хорошую стабильность дисперсии с увеличением твердости, прочности на разрыв и уменьшением износа композита Al-6065-Si, армированной УНТ.

Ключевые слова: многостенные углеродные нанотрубки (МУНТ), углеродные нанотрубки (УНТ), механические свойства, натрия дедосилсульфат.

\section{Introduction}

High strength to weight ratio, good wear resistance and high corrosion resistance materials are present day requirements in engineering applications. Materials reinforced with organics, ceramics and polymers exhibit improved properties. CNTs reinforced in aluminum metal found encouraging use in many engineering applications. However good dispersion of CNT in the base metal is challenging. Surface modification strategies and complementary routes must be incorporated in order to obtain compatibility between CNTs and aluminium matrices and hence to improve homogenous dispersion of composite materials. Many researchers adopted surface modification using ballmill approach on CNT and found experimental results show improvements in certain properties. Researchers have made investigations regarding the uniform dispersion of reinforcements which can be found by controlling the process parameters like stirring speed and time, molten metal and mould preheated temperature in the stir casting method. Manjunatha L. H. et. al., developed Al6061 based MMC's using Multi-Walled Carbon Nano tubes (MWCNT) as reinforcement by powder metallurgy and stir casting process. Microstructure analysis showed fairly uniform dispersion of MWCNTs with excellent bonding that exists between the CNTs with the base metal in the metal matrix composite [1]. Omkar Aranke, et al., studied the tribological behaviour of aluminium-7075 metal matrix composite reinforced with MWCNT with various weight percentages. They have fabricated the sample by the stir casting technique. Wear properties of MMCs were investigated using pin on disc apparatus and the results show that with increase in the percentage of reinforcements, there is a decrease in the wear rate of composite [2]. P.B. Senthil Kumar, et. al., focused on fabrication of CNTs reinforced with Al-6063, by stir casting method. The microstructure and mechanical properties was experimentally tested for various weight percentages of CNTs. They concluded that, the addition of MWCNTs in Al6063, increases its impact resistance and thereby decreasing the cracks along with voids in the crystal lattice as observed in XRD analysis [3]. The main objective of this research work is to develop an agglomeration free composite of SDS coated CNT reinforced in Al-6065-Si, and experimental study of mechanical properties. The study is focused on microstructure, mechanical and tribological behaviour of the MMC.

\section{Materials and method}

\subsection{Preparation of materials}

In this research, MWCNT reinforced Al6065-Si composites were fabricated by stir casting technique. The Al6065 ingots used as base material for matrix. MWCNTs are procured and surface modifications are made to avoid agglomeration using anionic SDS surfactant in the ratio 1:1 with $300 \mathrm{~mL}$ distilled water. The MWCNT and SDS surfactant were placed in a beaker and stirred with magnetic stirrer to obtain homogeneous mixture. The mixture was exposed to ultra-sonication for about 1 hour at room temperature $\left(28^{\circ} \mathrm{C}\right)$ to get better homogenization. After exposed to ultrasonication, water content in the mixture was found and removed in a hot air oven at $80^{\circ} \mathrm{C}$ for 12 hours. This process decreases the Vander Waals force between CNTs and hence to avoid agglomeration with better dispersion in the base metal. The dry CNT-SDS flakes grinded using mortar and pestle to obtain fine particles. The SDS coated MWCNT with fine particles were used as reinforced material to fabricate the MMCs. The CNT reinforced with $4 \%$ Silicon were added to Al6065 base material to fabricate specimens.

\subsection{Fabrication of MWCNT-Si-Al matrix of different weight percentages:}

The Al-6065 ingot-castings were placed in the electric furnace and the temperature of the crucible in the furnace was raised to $800^{\circ} \mathrm{C}$ and the molten metal was obtained. The temperature was later reduced to about $650^{\circ} \mathrm{C}$ for the casting process. The molten metal was stirred continuously while pouring the MWCNTs and Silicon particulate as mixture for about 15 mins. A three wing radial stirrer used for mixing the reinforced material in the crucible of height $300 \mathrm{~mm}$. The stirrer moved down inside the crucible to about $20 \mathrm{~mm}$ gap maintained from the bottom of the crucible and rotates with a speed of $500 \mathrm{rpm}$ with the help of electric motor. The SDS coated CNT powder slowly added and mixed in the molten metal. Impurities were separated using scum powder that accumulates at the top of the surface and removed. The degassing is help to produce sound castings $[4,5]$. In this process, the solid dry hexachloroethane $\left(\mathrm{C}_{2} \mathrm{Cl}_{6}\right)$ degasser tablets are added, to remove the gases from the molten alloy. This eliminates the air interrupted in the molten motel and to obtain the blow hole free castings [6]. This process is followed for $0.5,1.0,2.0,3.0$ and 4.0 wt.\% SDS coated MWCNTs reinforced in Al6065 with 4\% Silicon constant for all the samples (Table 1). The molten metal is poured into the metal die. Three samples of each specimen were fabricated for experimental investigations of properties. Microstructure of the CNTs and the Si powder is shown in Fig. 1a,b.

\section{Results and discussions}

\subsection{Microstructure analysis}

The fabricated specimens were polished and examined for metallographic study. The morphology of MWCNT-Al-Si 
Table 1. The composition of Specimens.

\begin{tabular}{|c|c|c|c|}
\hline Samples & MWCNTs & Silicon (Si) & Al-6065 \\
\hline 1 & 0 & 0 & $100 \%$ \\
\hline 2 & 0.5 wt.\% & 4 wt.\% & $95.5 \%$ \\
\hline 3 & 1 wt. $\%$ & 4 wt. $\%$ & $95 \%$ \\
\hline 4 & 2 wt. $\%$ & 4 wt. $\%$ & $94 \%$ \\
\hline 5 & 3 wt. $\%$ & 4 wt. $\%$ & $93 \%$ \\
\hline 6 & 4 wt. $\%$ & 4 wt. $\%$ & $92 \%$ \\
\hline
\end{tabular}

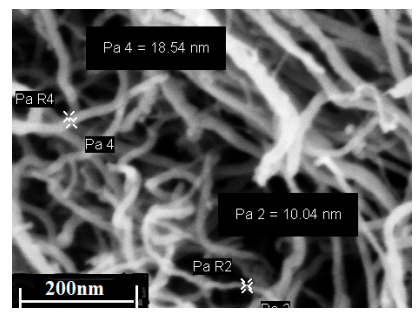

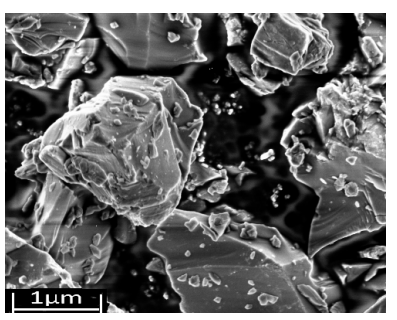

b
Fig. 1. Microstructure of CNTs (a) and Silicon powder (b).

metal matrix composite of different weight percentage of CNT specimens was observed under the Field Emission Scanning Electron Microscope (FE-SEM) to check the dispersion of Carbon Nano Tubes in the metal matrix (Fig. $2 \mathrm{a}-\mathrm{f}$ ). The SEM microstructure examination carried out with $1 \mu \mathrm{m}$ magnification.

Fig. 2 a depicts the pure Al6065 image indicating absence of porosity. Figs. $2 \mathrm{~b}-\mathrm{e}$ show fairly uniform dispersion of nanoparticles in the matrix. These samples exhibit better wetting and infiltration in the molten matrix alloy. The addition of MWCNT beyond 4.0 wt.\%, led to partial agglomeration and nano sized MWCNTs clusters were seen in Fig. $2 \mathrm{f}$. With increase beyond $4.0 \mathrm{wt}$.\% of reinforcements, wetting between MWCNTs and the base material becomes poor. This is because of MWCNT exhibits lower surface tension [7].

\subsection{Tensile strength testing}

The tensile test conducted by using Universal Testing Machine (Model: TUE-C-400). Samples were machined as per the ASTM E8-16a standard.

Experimental results (Fig. $3 \mathrm{a}$ ) show that tensile strength increased with increase of MWCNT composition from 0.0 to 2.0 wt.\% of CNT. Tensile strength increases from $122.3 \mathrm{MPa}$ (base alloy) to an average value of $174.33 \mathrm{MPa}$ (2.0 wt.\% MWCNTs). Thus, the average tensile strength of $2.0 \mathrm{wt} . \%$, of CNT in Al6065-Si MMC is increased by $42.54 \%$ as compared to the base alloy matrix shown in Fig. $3 \mathrm{~b}$. This is due to Orowan's mechanism of dislocation bypass over impenetrable obstacles where a dislocation bows out to result in the dislocation loop over the particles. A similar observation has been made by Murali et al. [8] and Onoro J [9] showing stress transfer from Al-Matrix to reinforced particles. The interaction of dislocation loops of the reinforced particles results in improvement in strength of the composites [10]. The improvement in the mechanical properties can also be as a result of the significant transfer of the tensile load to the uniform distribution of MWCNTs, the coupled effects due to grain refinement and the increase in the grain boundary area having strong thermal stress between the interface, induced by large difference in the coefficient of thermal expansion between the metal matrix and MWCNTs reinforcements. Further addition of MWCNTs above the 2 wt.\% value shall reduce the tensile strength and making the composite brittle. This may be due to higher agglomeration of nanoparticles and significant increase in the degree of porosity that is present in the nano-composite having higher MWCNTs content which was observed during fabrication of casting.

Fig. $4 \mathrm{~b}$ shows the tensile test results of percentage of elongation of the composite. The base alloy - Aluminium is ductile in nature and it is observed that, percentage

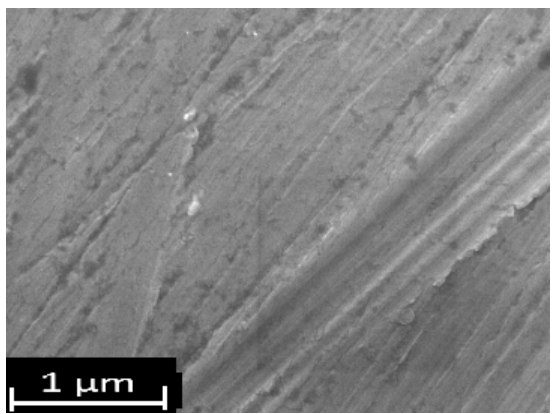

a

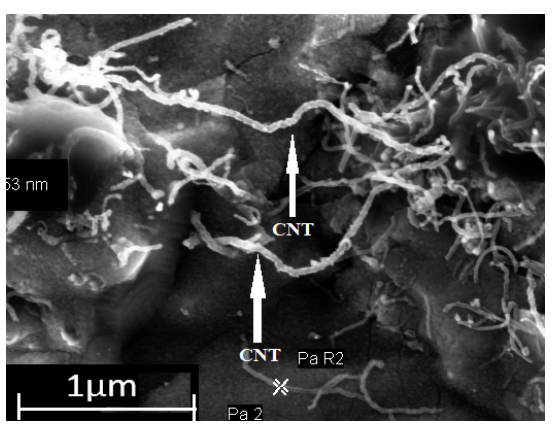

$\mathrm{d}$

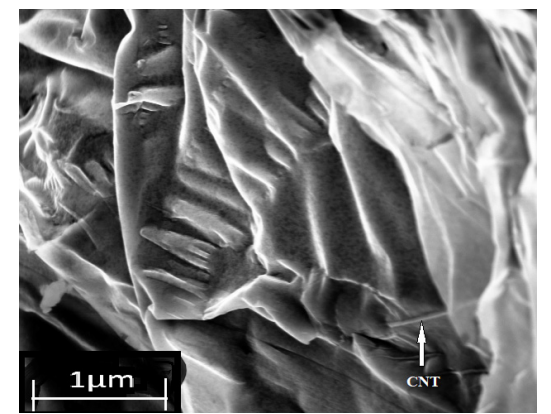

b

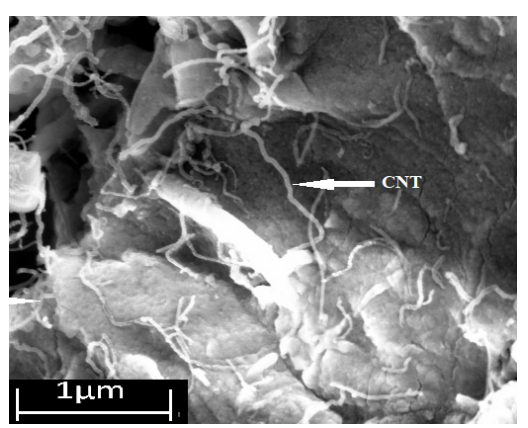

e

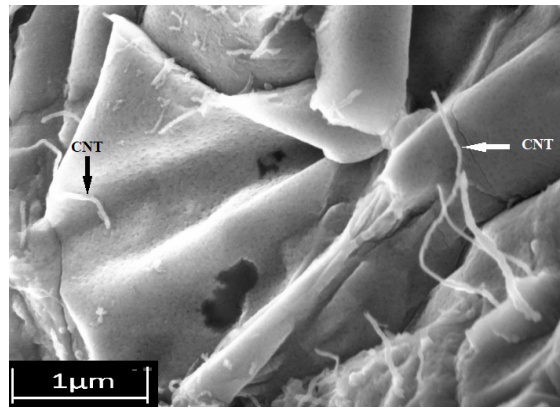

C

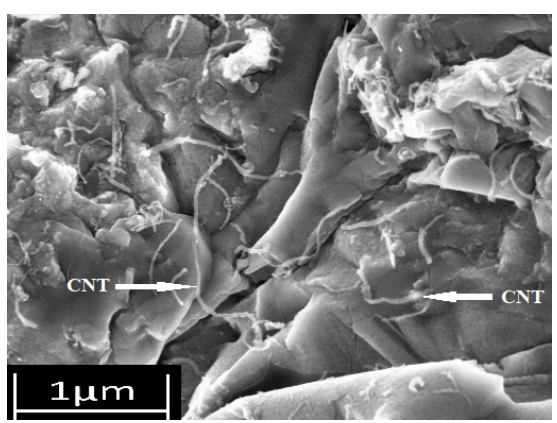

f

Fig. 2. Pure Al-6065 (a), 0.5 wt.\% MWCNT (b), 1.0 wt.\% MWCNT (c), 2.0 wt.\% MWCNT (d), 3.0 wt.\% MWCNT (e), 4.0 wt.\% MWCNT (f). 
of elongation decreases with increase in the percentage of MWCNT particles added. This may happen due the presence of hard reinforcement particles, which increases the brittleness of the composites [11]. The tensile tests show the addition of reinforcement leads to significant decrease in the percentage of the elongation from an average percentage value of 8.86 to 5.03 . The Fig. 5 shows the fracture surface found in the test sample ( $4 \mathrm{wt} . \%$ MWCNT) during the tensile test. The ductile fracture is replaced by brittle fracture with increase in the percentage of MWCNTs.

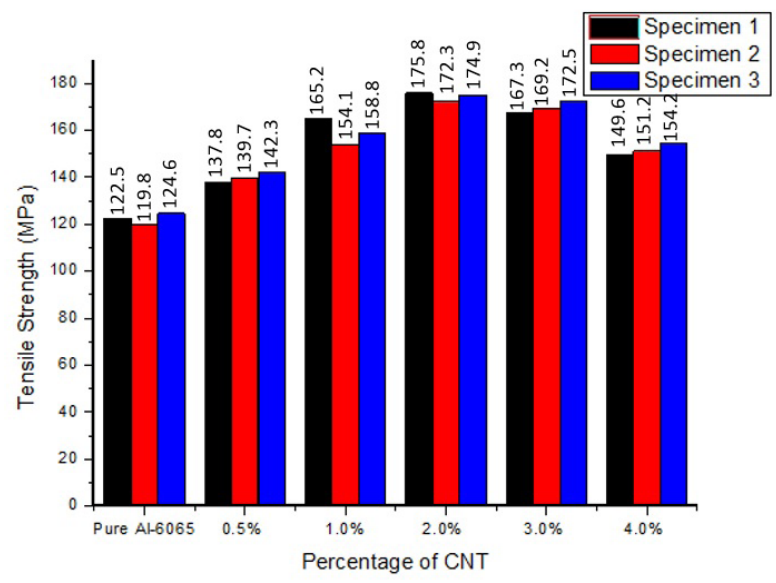

a

\subsection{Compressive strength testing}

The compressive strength of the specimen having $20 \mathrm{~mm}$ height and $13 \mathrm{~mm}$ in diameter, tested using Universal Testing Machine (UTM) according to the ASTM E9 standards. From the Fig. $6 \mathrm{~b}$, it can be seen that the compressive strength increases with increase in $3.0 \mathrm{wt} . \%$ of MWCNTs. The compressive strength of a MMCs is due to the grain refinement and the uniform dispersion of MWCNTs. The elastic modulus mismatch and the coefficient of thermal

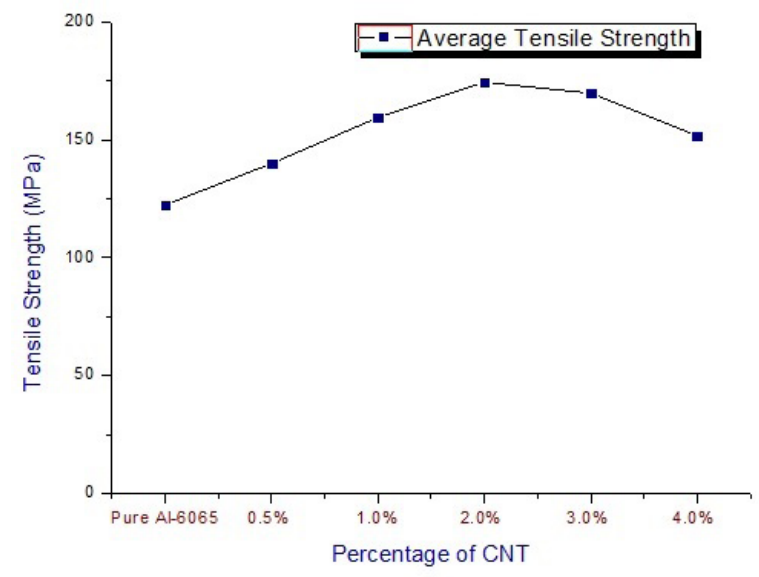

$\mathrm{b}$

Fig. 3. (Color online) Tensile strength - wt.\% of MWCNT in Al-Si MMC (a), average tensile strength - wt.\% of MWCNTs in Al-Si MMC (b).

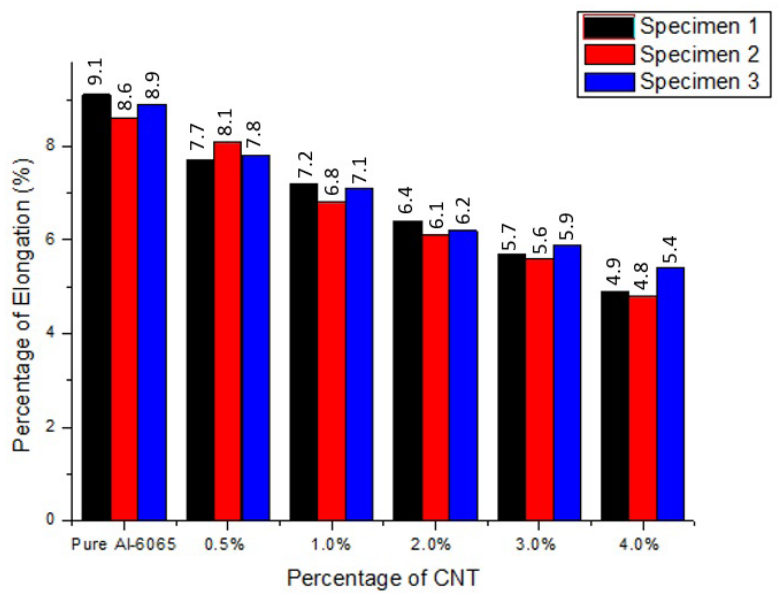

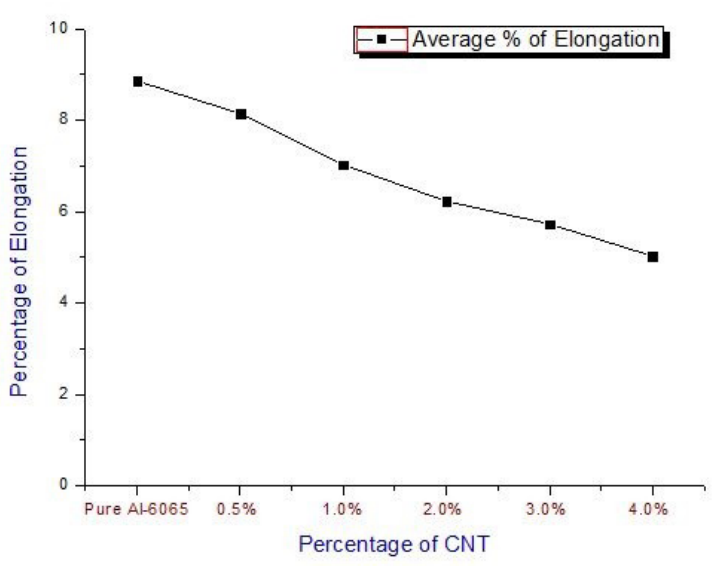

$\mathrm{b}$

Fig. 4. (Color online) Percentage of elongation - wt.\% of MWCNT in Al6065-Si MMC (a), average percentage of elongation - wt.\% of MWCNT in Al6065-Si MMC (b).
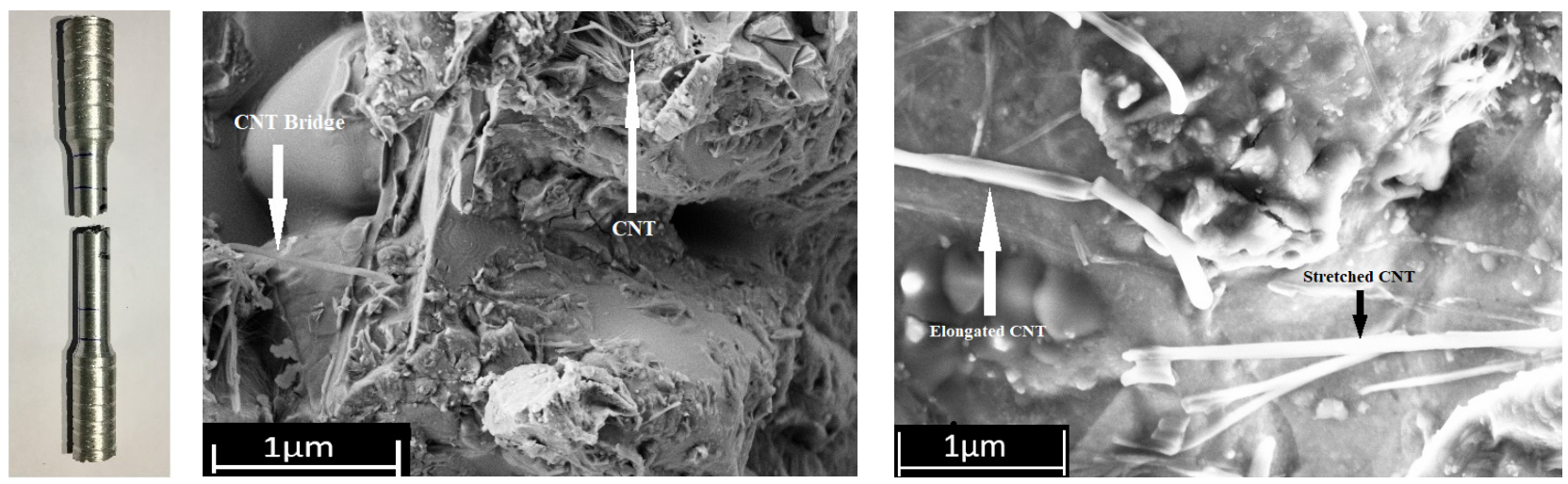

Fig. 5. Samples of tensile fracture surface of 4 wt.\% MWCNT. 
expansion mismatch between the matrix and reinforcement phase, along with load transfer in matrix to reinforcement phase results in dislocation generation [12]. The results show the nanocomposites having greater compressive strength than that of base alloy at value of $3.0 \mathrm{wt} . \%$ as MWCNTs are more effective in strengthening the composites.

Due to the effect of grain size, the compressive strength of reinforcing particles at $3.0 \mathrm{wt} . \%$ value is more than that of base alloy. The excessive CNT content results in decreasing the value of compressive strength at $4.0 \mathrm{wt} . \%$. The reinforced composite may be due to floating of CNTs due to poor wettability, and also the difficulties of MWCNTs billets infiltration during stirring, that results in agglomeration and un-recovered clusters in MWCNTs [13].

\subsection{Hardness testing}

The hardness test was carried out as per ASTM E92 standards with Vickers hardness testing machine (ModelBV 250) with $10 \mathrm{~mm}$ diamond indenter and $50 \mathrm{~N}$ load. The hardness test was carried out at a room temperature of $28^{\circ} \mathrm{C}$. Vickers hardness measurements conducted at three different locations of every sample and obtained an average hardness value.

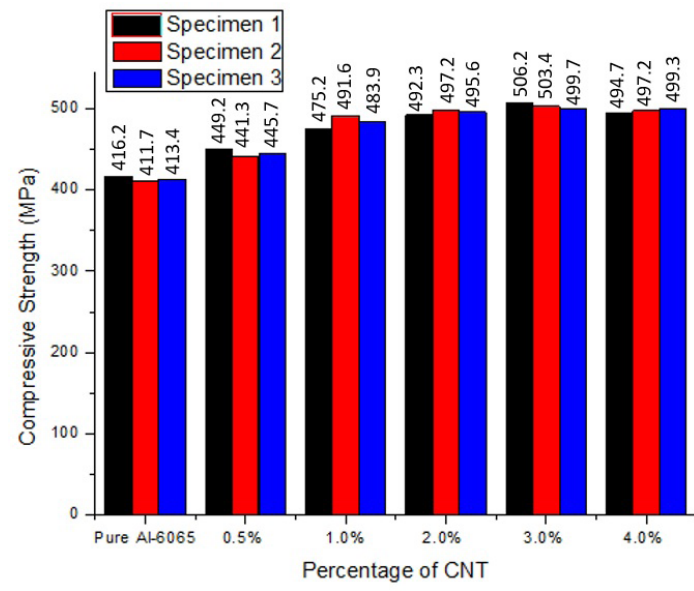

a
Fig. $7 \mathrm{~b}$ shows the effect on addition of MWCNTs having different weight percentages by Vickers hardness of Al6065 alloy. The hardness values of 0.5, 1.0, 2.0, 3.0 and 4.0 wt.\% MWCNTs are higher as compared to base metal Al6065. The significant improvement in the hardness is due to solitary strengthening effects of nanotubes. The hardness increased from an average of $39.53 \mathrm{VHN}$ for the base alloy to about 54.9 VHN for 3.0 wt.\% of MWCNT (Fig. $7 \mathrm{~b}$ ). This shows $38.8 \%$ of increase in hardness value at $3.0 \mathrm{wt} . \%$. However, the hardness falls beyond $3.0 \mathrm{wt}$.\% MWCNT. This drop variation can be due to the agglomeration effects and also due to the non-uniform dispersion of the particles in the MMCs. This may have arisen due to the excess addition of weight fraction of MWCNT.

\subsection{Wear test}

A computational approach called pin on disc test is used to study the tribological condition of the MWCNT-Al6065-Si MMC. The samples were prepared as per ASME G99 standards [14]. The tests carried out with a load of $5 \mathrm{~kg}$ and the specimen sliding on the disc at a rotation speed of $600 \mathrm{rpm}$. The amount of wear in microns measured for duration of 900 seconds and plotted as a function of time, indicated in Fig. 8.

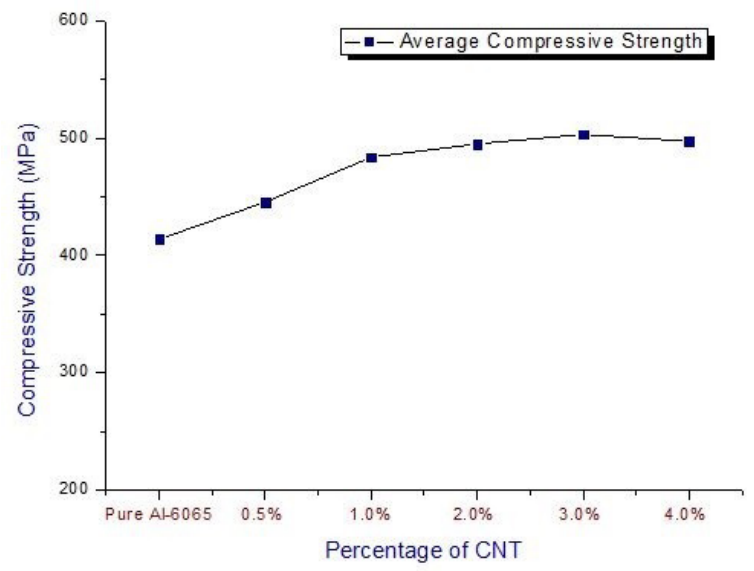

b

Fig. 6. (Color online) Compressive strength - wt. \% of MWCNT in Al6065-Si MMC (a), average compressive strength - wt.\% of MWCNT in Al6065-Si MMC (b).

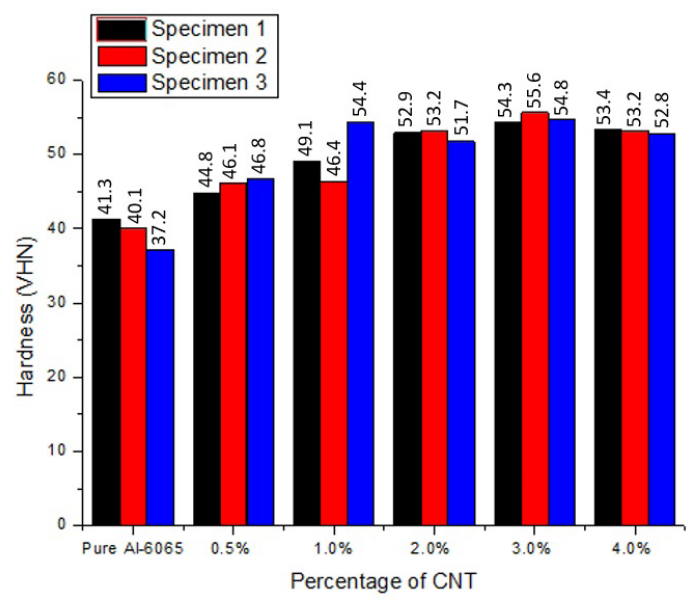

a

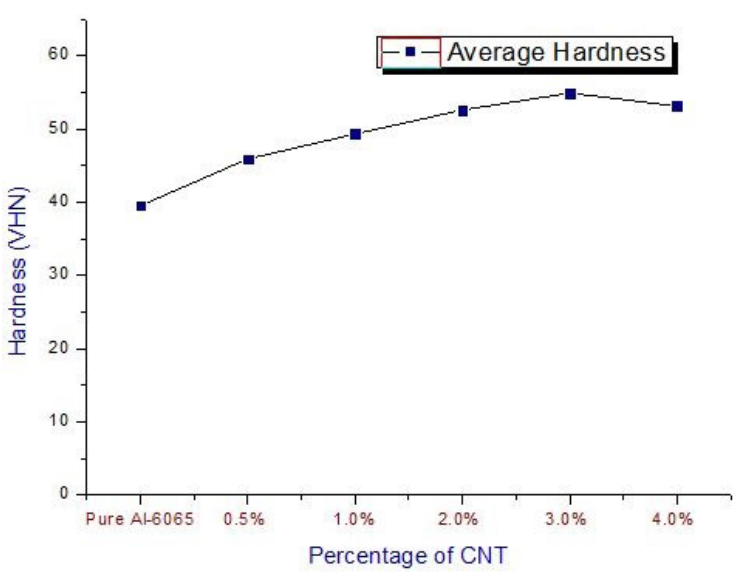

$\mathrm{b}$

Fig. 7. (Color online) Hardness - wt.\% of MWCNT in Al6065-Si MMC (a), average hardness - wt.\% of MWCNT in Al6065-Si MMC (b). 
The presence of wear resistance of hard MWCNT particles decreases the wear of aluminium composite. It is observed in the Fig. 8, that the addition of reinforced material decreases the amount of wear. This is due to interactions between the dislocations and the MWCNT particles that resist the propagation of cracks during sliding wear.

The strain fields created over the MWCNT particles due to the thermal mismatch between the aluminum alloy and MWCNT particle during solidification. Subsequent removal of materials and crack resistance is offered by the strain fields. This also results in the Orowan strengthening which is due to the homogeneous distribution of MWCNT particles [15]. The clear interface and bonding, delay the detachment of particles from the aluminum matrix. Thus, the wear resistance of Aluminium Metal Matrix Composites (AMMCs) is enhanced by MWCNT particles.

However, as compared to $3.0 \mathrm{wt} . \%$ of MWCNT, there is small amount of increase in the wear at $4.0 \mathrm{wt} \%$ of MWCNT. This results in porosity, cracks and deterioration of mechanical properties [16]. Thus, with increase in wt.\% of reinforcement till the $3.0 \mathrm{wt} . \%$ fraction of MWCNT in the Al6065-Si MMC exhibit higher wear resistance.

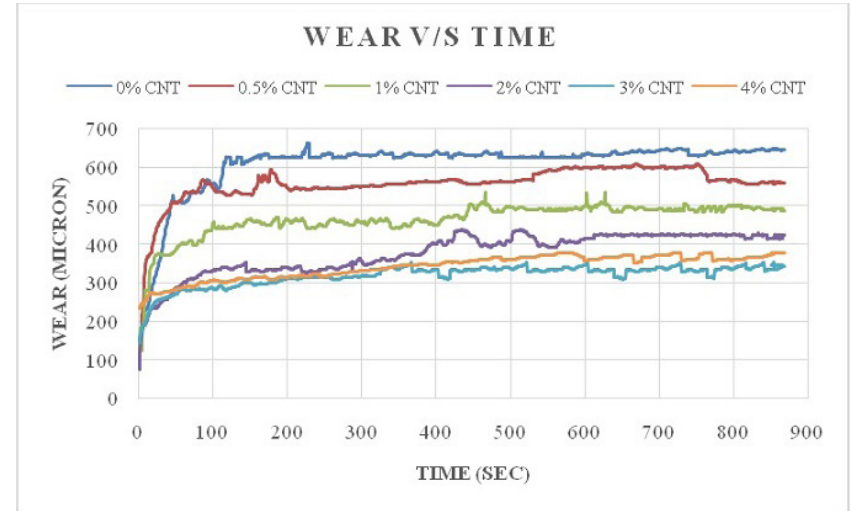

Fig. 8. (Color online) Wear - wt.\% of MWCNT in Al6065-Si matrix.

\section{Conclusions}

The reinforced MWCNT in Al6065-Si composites fabricated by stir casting technique. The surface of the MWCNT modified for better dispersion and to avoid agglomeration using anionic SDS surfactant. Composite material was prepared for different weight percentage of CNT having 0.5, 1.0, 2.0, 3.0 and 4.0 wt.\% MWCNTs reinforced in Al6065-Si MMC, and keeping 4\% Silicon constant for all the samples. The morphology of MWCNT-Al6065-Si composite was found that there is uniform dispersion of nanoparticles in the matrix till 4.0 wt.\% of reinforcement. Beyond 4.0 wt.\%, led to partial agglomeration and nano sized MWCNTs clusters within the composite. Tensile strength increases from 122.3 $\mathrm{MPa}$ for the base alloy to an average value of $174.33 \mathrm{MPa}$. for $2.0 \mathrm{wt}$.\% MWCNTs reinforced composite. The interaction between the dislocation loop of reinforcement particles results in an improved in strength of composites till $3 \mathrm{wt} . \%$ of CNT and any further increase in the addition of CNT reduces the tensile strength. It is observed that the percentage of elongation reduced with increase in percentage of MWCNT particles. Tensile tests also reveal that the addition of reinforcement leads to significant decrease in the percentage of the elongation from an average percentage value of 8.86 to 5.03 . The compressive strength increases till 3.0 wt.\% of MWCNTs. The excessive CNT content results in decreasing the value of compressive strength at $4.0 \mathrm{wt} . \%$. The hardness test conducted using Vickers hardness testing machine at $50 \mathrm{~N}$ load shows a $38.8 \%$ of increase in hardness value till 3.0 wt.\% of reinforcement. However, the hardness falls after $3.0 \mathrm{wt} . \%$ MWCNT addition. Wear resistance of AMMCs is enhanced with the addition of MWCNT particles. This shows that, with increase in wt.\% of reinforcement till the 3.0 wt.\% fraction of MWCNT in the Al6065-Si exhibit higher wear resistance. This concludes that, the SDS coated MWCNT avoids the agglomeration in the composite and improves the mechanical properties. Beyond the 3 wt.\% addition of the filler material results in lowers the properties of matrix material.

\section{References}

1. L. H. Manjunatha, P. Dinesh. ARPN Journal of Engineering and Applied Sciences. 8, 229 (2013).

2. O. Aranke, C. Gandhi, N. Dixit, P. Kuppan. Materials today: Proceedings. 5, 7748 (2018). Crossref

3. P. B. Senthil kumar, R. Hushein, K. Logesh, K. Inbarasan. International Journal of Mechanical Engineering and Technology. 8, 1383 (2017).

4. L. Zhao, Y Pan, H Liao, Q Wang. Materials Letters. 66, 328 (2012). Crossref

5. R. Haghayeghi, H. Bahai, P. Kapranos. Materials Letters. 82, 230 (2012). Crossref

6. R. Adat, S. Kulkarni, S. Kulkarni. International Journal of Current Engineering and Technology. 5, 2808 (2015).

7. A.B. Elshalakany, T. A. Osman, A. Khattab, B. Azzam, M. Zaki. Hindawi Publishing Corporation Journal of Nanomaterials. 2014, 386370 (2014). Crossref

8. M. Murali, M. Sambathkumar. M.S. Senthil Saravanan. Universal Journal of Materials Science. 2(3), 49 (2014).

9. J. Onoro. Rare Metals. 30, 200 (2011). Crossref

10. B. K.C. Ganesh, W. Sha, N. Ramanaiah, A. Krishnaiah. Materials and Design. 56, 480 (2014). Crossref

11. D.S. Prasad, C. Shoba, N. Ramanaiahet. Journal of Material Research and Technology. 3, 79 (2014). Crossref

12. S. R. Bakshi, A. Agarwal. Carbon. 49, 533 (2011). Crossref

13. R.M. Rashad, O.M. Awadallah, A.S. Wifi. Journal of Achievements in Materials and Manufacturing Engineering. 58, 74 (2013).

14. P. Sahoo, S. Ghosh. Journal of Tribology Research. 2, 1 (2011).

15. B. Chen, J. Shen, X. Ye, L. Jia, S. Li, J. Umeda, M. Takahashi, K. Kondoh. Acta Materialia. 140, 317 (2017). Crossref

16. A Baradeswaran, A. ElayaPerumal. Composites Part B Engineering. 56, 472 (2014). $\underline{\text { Crossref }}$ 